\title{
KEMAMPUAN BELANJA PEMERINTAH DAN PERTUMBUHAN EKONOMI DALAM MENURUNKAN TINGKAT KEMISKINAN: BUKTI EMPIRIS DARI SUMATERA DAN JAWA
}

\author{
Roosemarina Anggraini Rambe ${ }^{1)}$, Purmini $^{2)}$ \\ ${ }^{1,2}$ Jurusan Ekonomi Pembangunan,Fakultas Ekonomi dan Bisnis,Universitas Bengkulu,Indonesia \\ 1oosemarina.rambe@unib.ac.id, ${ }^{2}$ purmini@unib.ac.id
}

\begin{abstract}
The objective of the research is to analyze the effect of government expenditure, economic growth and previous poverty rate on the current poverty rate in Java and Sumatra. The data set was 267 local governments in year 2017. The method used in this research was multiple regression. Results show that government expenditure and economic growth affect significantly positively the poverty rate. While the previous poverty rate has negative effect on the current poverty rate. Local governments in Java and Sumatra should make appropriate programmes and activities and allocate optimally their expenditures to build the new SMEs and improve the existing SMEs abilities in order to reduce the poverty rate.
\end{abstract}

Keywords : A Previous Poverty Rate ${ }^{1}$, Economic Growth ${ }^{2}$, Government Expenditure ${ }^{3}$, Poverty Rate $^{4}$

\section{PENDAHULUAN}

Indonesia merupakan negara kepulauan yang memiliki 548 pemerintah daerah (514 pemerintah kabupaten/kota dan 34 pemerintah provinsi). Pulau dengan jumlah pemerintah daerah terbanyak adalah Sumatera yang diikuti oleh Jawa. Dengan 113 kabupaten dan kota yang tersebar di dalam 6 provinsi, pulau Jawa memiliki jumlah belanja pemerintah terbesar di Indonesia selama tahun 2015-2017 (Gambar 1). Pulau Sumatera, dengan 154 kabupaten/kota yang tersebar dalam 10 provinsi, menduduki posisi kedua setelah Jawa. Walaupun jumlah pemerintah daerah di Jawa lebih sedikit daripada Sumatera, namun belanja pemerintah di Jawa lebih besar karena Jawa merupakan pulau dengan kepadatan penduduk terbesar.

Besarnya belanja pemerintah seharusnya digunakan untuk menghasilkan peningkatan pelayanan dan kesejahteraan masyarakat, yang salah satu indikasinya adalah menurunnya jumlah penduduk miskin di wilayah tersebut. Namun penurunan jumlah penduduk miskin di kedua pulau ini (Jawa dan Sumatera) tidak lebih baik daripada pulau-pulau lainnya di 
Indonesia walaupun belanja pemerintah di kedua pulau tersebut jauh lebih besar. Hal ini ditunjukkan dalam Gambar 2.

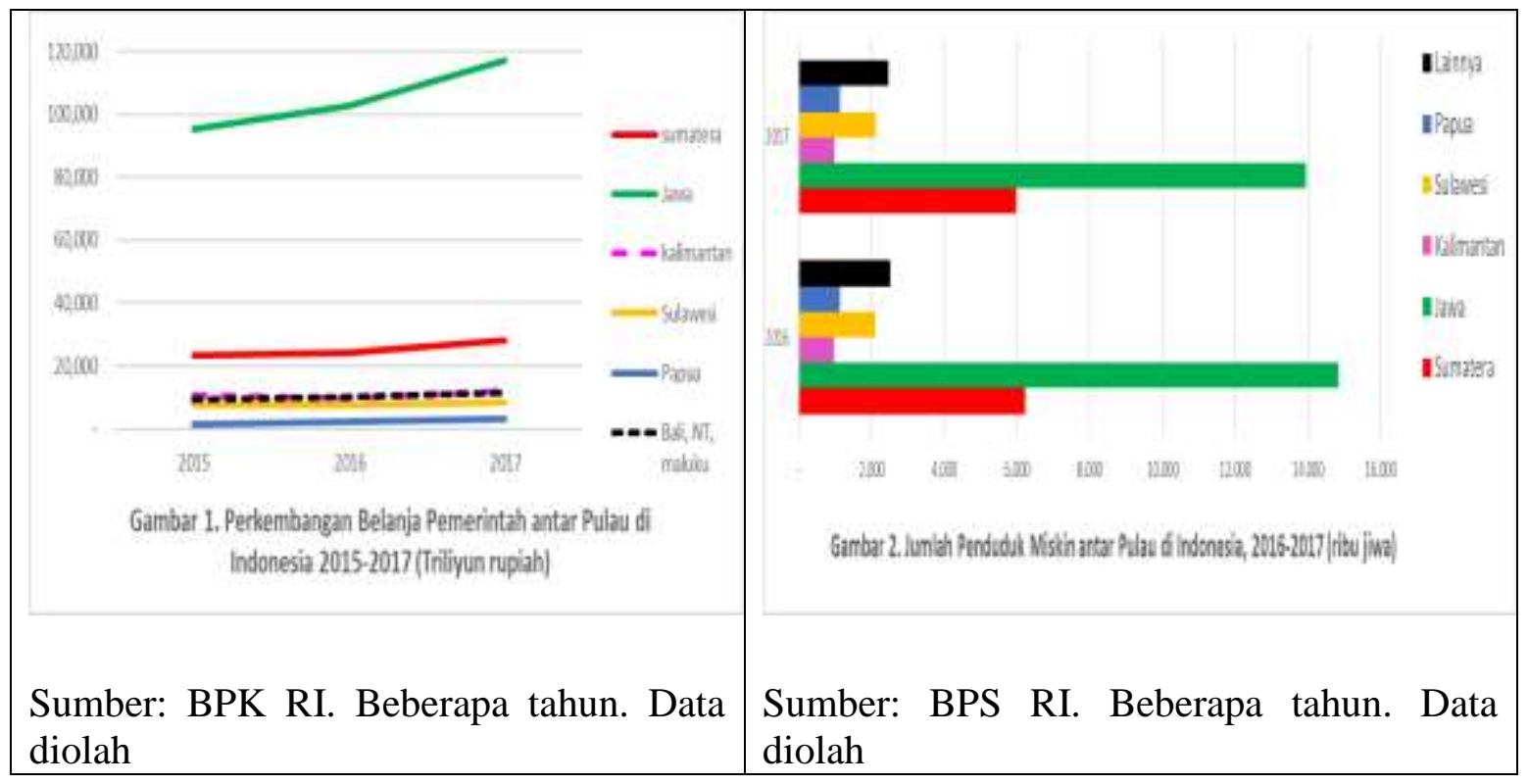

Hal ini menjadi menarik untuk diteliti bagaimana peran pemerintah dalam menurunkan tingkat kemiskinan di pulau Jawa dan Sumatera, karena dengan keterbatasan dana negara, seharusnya pemerintah mampu membuat program dan menciptakan aktivitas yang dapat mengurangi tingkat kemiskinan (pro-poor program) di kedua pulau ini.

Selain belanja pemerintah, faktor lain dinilai juga menjadi determinan tingkat kemiskinan seperti pertumbuhan ekonomi. Pertumbuhan ekonomi sering dianggap sebagai syarat keharusan dalam pengentasan kemiskinan. Dengan adanya pertumbuhan ekonomi, kemiskinan dapat dikurangi. Bahkan pertumbuhan ekonomi tahun-tahun yang lalu masih berperan dalam menurunkan kemiskinan masyarakat (Ginting dan Dewi, 2013). Tujuan dalam penelitian ini ialah untuk menganalisis peran belanja pemerintah, pertumbuhan ekonomi, dan tingkat kemiskinan tahun sebelumnya dalam menurunkan kemiskinan di pulau Jawa dan Sumatera.

\section{TINJAUAN PUSTAKA}

Kemiskinan berkaitan dengan berbagai aspek kehidupan yang sangat luas. Konsep sederhana kemiskinan merupakan kondisi seseorang yang tidak mampu memenuhi kebutuhan minimal hidupnya secara ekonomi seperti kebutuhan pangan, pakaian dan perumahan. Secara luas kemiskinan merupakan konsep yang multidimensi, di mana orang 
miskin secara ekonomi, juga miskin dalam aspek sosial, budaya bahkan politik. Dalam realita, orang miskin mengalami keterbatasan untuk memperoleh pendidikan, kesehatan, kehidupan sosial, budaya dan politik.

Sangat banyak negara yang belum mampu keluar dari kemiskinan, termasuk Indonesia. Untuk itu, menjadi prioitas bagi semua negara untuk mengentaskan kemiskinan. Urgensi pentingnya mengatasi permasalahan kemiskinan tercermin dari 17 tujuan SDGS (Sustainable Development Goals) yang menempatkan pengentasan kemiskinan sebagai tujuan pertama. Kemiskinan termasuk dalam pilar sosial dalam pembangunan berkelanjutan (Alisjahbana dan Murniningtyas, 2018).

Walaupun telah menjadi salah satu tujuan pembangunan dalam SDGs dan menjadi prioritas banyak pemerintahan untuk menurunkan tingkat kemiskinan, namun kemiskinan masih menjadi "penyakit ekonomi" yang sampai saat ini belum dapat diobati. Banyak faktor yang menyebabkan masyarakat menjadi miskin dan sulit untuk keluar dari lingkaran kemiskinan (vicious circle of poverty), seperti produktivitas rendah dan kesehatan yang buruk (Kuncoro, 2013).

Selain itu, kebijakan pemerintah juga menjadi determinan kemiskinan. Menurut Sukirno (Adisasmita, 2011), pemerintah dapat mempengaruhi corak pembangunan dan kegiatan ekonomi melalui alokasi dan distribusi pengeluaran pemerintah di daerah. Belanja pemerintah menggambarkan aktivitas pemerintah, sehingga, belanja pemerintah dapat dijadikan sebagai indikator kegiatan pemerintah. Semakin besar kegiatan pemerintah maka akan semakin besar juga belanja pemerintah. Biasanya belanja pemerintah akan bertambah besar jika kegiatan perekonomian semakin besar.

Namun, meskipun pengeluaran pemerintah cenderung meningkat, peningkatan ini belum tentu berakibat baik terhadap aktivitas perekonomian. Jika program atau kegiatan pemerintah tidak menyentuh pada aktivitas ekonomi masyarakat, maka tidak akan terjadi multiplier effect yang positif pada perekonomian. Selain itu pengeluaran pemerintah rentan dengan pemborosan dan inefisiensi. Pengeluaran yang tidak terencana dan tidak terkendali dengan baik akan menjadi sumber inefisiensi dan pemborosan uang negara yang sangat merugikan masyarakat (Mahmudi, 2010). 
Belanja pemerintah daerah, yang dikelompokkan menjadi belanja langsung dan tidak langsung, dituangkan dalam APBD, baik untuk urusan wajib maupun urusan pilihan pemerintah daerah tersebut. Melalui urusan wajib, pemerintah daerah ditugaskan untuk meningkatkan kesejahteraan masyarakat dan mengentaskan kemiskinan di daerah. Dengan kata lain, penanggulangan kemiskinan menjadi tugas pemerintah. Berbagai program dan aktivitas pemerintah ditujukan untuk meningkatkan kesejahteraan masyarakat dan mengentaskan kemiskinan. Walaupun kadang kala pemerintah tidak berhasil.

Determinan kemiskinan yang lain adalah pertumbuhan ekonomi. Pertumbuhan ekonomi merupakan peningkatan produksi barang dan jasa dalam suatu wilayah dalam jangka waktu satu tahun (Kuncoro, 2013). Dalam jangka panjang, pertumbuhan ekonomi menunjukkan adanya peningkatan kemampuan masyarakat untuk memenuhi standar materi kehidupan dalam suatu wilayah sepanjang waktu. Peningkatan kemampuan masyarakat tercermin dari pendapatan yang terus meningkat. Peningkatan pendapatan akan mendorong kemampuan masyarakat untuk mengkonsumsi barang dan jasa yang lebih banyak dan lebih beragam (Mankiw, 2007).

\section{Penelitian Empiris}

Peran belanja pemerintah dan pertumbuhan ekonomi dalam menurunkan tingkat kemiskinan telah diteliti di berbagai wilayah. Proksi belanja pemerintah yang digunakan dalam penelitian tersebut bervariasi, seperti belanja per sektor seperti sektor pendidikan, pertanian, dan infrastruktur (Fan, Hazell, \& Thorat, 2000; Fan \& Zhang, 2008; Sasmal \& Sasmal, 2016). Sementara itu Tsai dan Huang (2016) dan Celikay dan Gumus (2017) menggunakan share belanja pemerintah/GDP sebagai proksi belanja pemerintah. Selain itu proksi belanja pemerintah per kapita juga digunakan dalam penelitian yang dilakukan oleh Madzinová (2017) dan Hidalgo-Hidalgo dan Iturbe-Ormaetxe (2018).

Penelitian mengenai kaitan belanja pemerintah dengan tingkat kemiskinan menunjukkan bahwa ada pengaruh negatif belanja pemerintah terhadap tingkat kemiskinan. Hal ini ditemukan oleh Fan, Hazell dan Thorat (2000), Fan dan Zhang (2008), Sasmal dan Sasmal (2016), Tsai dan Huang (2016), Celikay dan Gumus (2017), Madzinová (2017), serta Hildalgo-Hidalgo dan Iturbe-Ormaetxe (2018). Dengan kata lain, penelitian-penelitian tersebut menunjukkan bahwa belanja pemerintah dapat menurunkan tingkat kemiskinan. 
Namun demikian ada penelitian yang mengungkapkan tidak adanya pengaruh belanja pemerintah terhadap penurunan tidak kemiskinan (Chambers, Wu dan Yao, 2008; Affandi dan Astuti, 2013).

Dari penjelasan tersebut, maka hipotesis yang akan diuji dalam penelitian ini adalah:

Belanja pemerintah memiliki pengaruh negatif terhadap tingkat kemiskinan.

Selanjutnya diuraikan peran pertumbuhan ekonomi dalam mengurangi kemiskinan Beberapa referensi menjelaskan bagaimana peran pertumbuhan ekonomi dalam mengurangi kemiskinan. Bourguignon (Chambers, Wu, Yao, 2008) mengemukakan peran pertumbuhan ekonomi dengan pengurangan kemiskinan. Bourguignon menyebutkan bahwa di wilayah yang awalnya miskin, pertumbuhan ekonomi cenderung memiliki dampak besar pada penurunan kemiskinan. Demikian juga hasil penelitian SMERU Research Institute, yang melakukan studi tentang kemiskinan di Indonesia tahun 2002 (Kuncoro, 2003). Hasil penelitian SMERU ini mengungkapkan adanya hubungan negatif pertumbuhan ekonomi dengan kemiskinan. Ketika ekonomi tumbuh, kemiskinan berkurang, dan sebaliknya. Bahkan beberapa penelitian menunjukkan bahwa pertumbuhan ekonomi di tahun-tahun sebelumnya (time lag) berperan dalam mengurangi tingkat kemiskinan (Kuncoro, 2013; Fan, Hazel dan Thorat, 2000).

Proksi pertumbuhan ekonomi yang digunakan dalam penelitian empiris bervariasi untuk melihat pengaruh pertumbuhan ekonomi terhadap kemiskinan, seperti GDP riil per kapita (Chambers, Wu dan Yao, 2008), GDP per kapita (Affandi dan Astuti, 2013; Sasmal dan Sasmal, 2016; Hidalgo-Hidalgo dan Iturbe-Ormaetxe, 2018) dan GDP (Olavarria-Gambi, 2003). Pertumbuhan ekonomi yang menggambarkan perubahan GDP dalam satu tahun juga digunakan sebagai proksi untuk melihat kaitannya dengan kemiskinan (Ginting dan Dewi, 2013; Perera dan Lee, 2013). Selain itu, pertumbuhan ekonomi sektoral juga menunjukkan adanya pengaruh negatif terhadap kemiskinan (Jayadi dan Bata, 2016).

Dari proksi pertumbuhan ekonomi yang diuraikan tersebut, ditemukan adanya pengaruh pertumbuhan ekonomi dalam menurunkan kemiskinan, dengan kata lain, adanya pengaruh negatif pertumbuhan ekonomi terhadap kemiskinan. informasi ini diungkapkan oleh Olavarria-Gambi (2003), Chambers, Wu dan Yao (2008), Affandi dan Astuti (2013), 
Ginting dan Dewi (2013), Perera dan Lee (2013), Jayadi dan Bata (2016), Sasmal dan Sasmal (2016), Tsai dan Huang (2016). Namun demikian, sebaliknya, ada penelitian yang menyebutkan tidak ada pengaruh pertumbuhan ekonomi yang signifikan terhadap kemiskinan (Hildalgo-Hidalgo dan Iturbe-Ormaetxe, 2018).

Berdasarkan penjelasan tersebut, maka hipotesis yang dibangun dalam penellitian ini adalah:

Pertumbuhan ekonomi memiliki pengaruh negatif terhadap tingkat kemiskinan.

Variabel independen lain yang digunakan dalam penelitian ini adalah tingkat kemiskinan tahun sebelumnya (time lag t-1). Vicious circle of poverty menjelaskan bahwa dengan segala keterbatasan yang dimiliki orang miskin menyebabkan mereka sulit keluar dari kemiskinan. Dengan demikian, kemiskinan masyarakat pada tahun-tahun sebelumnya menjadi salah satu penyebab masyarakat tetap menjadi miskin sekarang ini. Diperlukan waktu yang lama untuk mengurangi tingkat kemiskinan dalam masyarakat. Variabel tingkat kemiskinan tahun sebelumnya masih belum banyak diteliti sehingga ini menjadi kontribusi penelitian ini.

Hipotesis penelitian untuk variabel ini adalah:

Tingkat kemiskinan tahun sebelumnya memiliki pengaruh positif terhadap kemiskinan tahun sekarang.

\section{METODE PENELITIAN}

Variabel yang digunakan dalam penelitian ini belanja pemerintah, pertumbuhan ekonomi dan tingkat kemiskinan tahun ini dan tingkat kemiskinan tahun sebelumnya (time lag t-1). Data yang digunakan dalam penelitian ini adalah data sekunder yang diperoleh dari BPK dan BPS. Jumlah pemerintah kabupaten dan kota yang dianalisis adalah 267 pemerintah kabupaten dan kota di pulau Jawa dan Sumatera tahun 2017.

Untuk menjawab tujuan penelitian, penelitian ini menggunakan alat analisis regresi berganda. Adapun model regresi dalam penelitian ini adalah:

$\operatorname{Pov}=\mathrm{a}+\beta_{1} \operatorname{Pov}_{\mathrm{t}-1} \quad \beta_{2} \ln \mathrm{E}+\beta_{3} \mathrm{G}+\mathrm{e}$ 
Di mana Pov adalah tingkat kemiskinan tahun ini, Pov $_{\mathrm{t}-1}$ merupakan tingkat kemiskinan tahun sebelumnya, E adalah belanja pemerintah kabupaten/kota, G menunjukkan pertumbuhan ekonomi. Selanjutnya dengan $a=5 \%$, dilakukan uji $\mathrm{F}$ dan uji t untuk menguji hipotesis penelitian. Uji $\mathrm{F}$ dipakai untuk melihat pengaruh variabel-variabel independen secara keseluruhan, sedangkan uji t dipakai untuk melihat signifikansi pengaruh variabel independen secara individu terhadap variabel (Gujarati, 2006).

Uji F :

$\mathrm{H} 0: \beta_{1}, \beta_{2}, \beta_{3}=0$

Ha: $\beta_{1}, \beta_{2}, \beta_{3} \neq 0$

Kriteria pengujian hipotesis adalah:

Jika $\mathrm{F}_{\text {hitung }}<\mathrm{F}_{\text {tabel}}$, maka H0 tidak ditolak, yang artinya semua variabel independen secara bersama-sama tidak mempengaruhi kemiskinan.

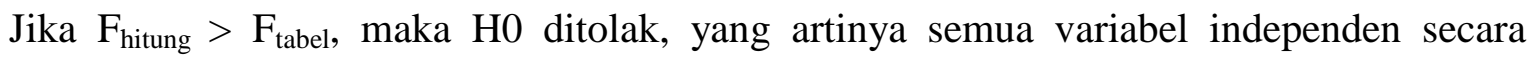
bersama-sama mempengaruhi kemiskinan.

Sementara itu, hipotesis untuk uji parsial (uji-t):

$\mathrm{H} 0: \beta_{\mathrm{i}}=0$

Ha: $\beta_{\mathrm{i}} \neq 0$

Kriteria pengujian parsial

Jika $t_{\text {hitung }}<t_{\text {tabel }}$ maka H0 tidak ditolak, yang artinya variabel independen secara parsial tidak mempengaruhi kemiskinan.

Jika $\mathrm{t}_{\text {hitung }}>\mathrm{t}_{\text {tabel }}$ maka $\mathrm{H} 0$ ditolak, yang artinya variabel independen secara pasial mempengaruhi kemiskinan secara positif.

\section{HASIL DAN PEMBAHASAN}

Pengolahan data dengan menggunakan software E views version 9.0. Sebelum diuraikan hasil pengolahan data yang menghasilkan model regresi, terlebih dahulu ditampilkan deskripsi data variabel yang diteliti yaitu rata-rata variabel kabupaten dan kota di setiap provinsi untuk pulau Jawa dan pulau Sumatera. 
Variabel yang diuraikan pertama di sini adalah tingkat kemiskinan pada tahun 2016 dan 2017 (Gambar 3a dan 3b). Di Sumatera tahun 2016, tingkat kemiskinan berkisar antara 5,34\%-17,06\% di tahun 2016, di mana tingkat kemiskinan kabupaten/kota rata-rata tertinggi di provinsi NAD, sebaliknya, tingkat kemiskinan kabupaten/kota terendah berada di provinsi Bangka Belitung. Di tahun 2017, tingkat kemiskinan rata-rata kabupaten/kota di kedua provinsi ini sama-sama meningkat. Namun demikian, secara rata-rata di Sumatera ada penurunan kemiskinan di tingkat kabupaten/kota walaupun sangat kecil penurunannya, yaitu sebesar 0,22\%. Selama 2016-2017, terjadi penurunan tingkat kemiskinan kabupaten/kota rata-rata di tujuh provinsi. Kabupaten/kota yang paling berhasil menurunkan tingkat kemiskinan pada tahun 2017, dengan penurunan tingkat kemiskinan sebesar 0,71\%, terdapat di Provinsi Bengkulu.

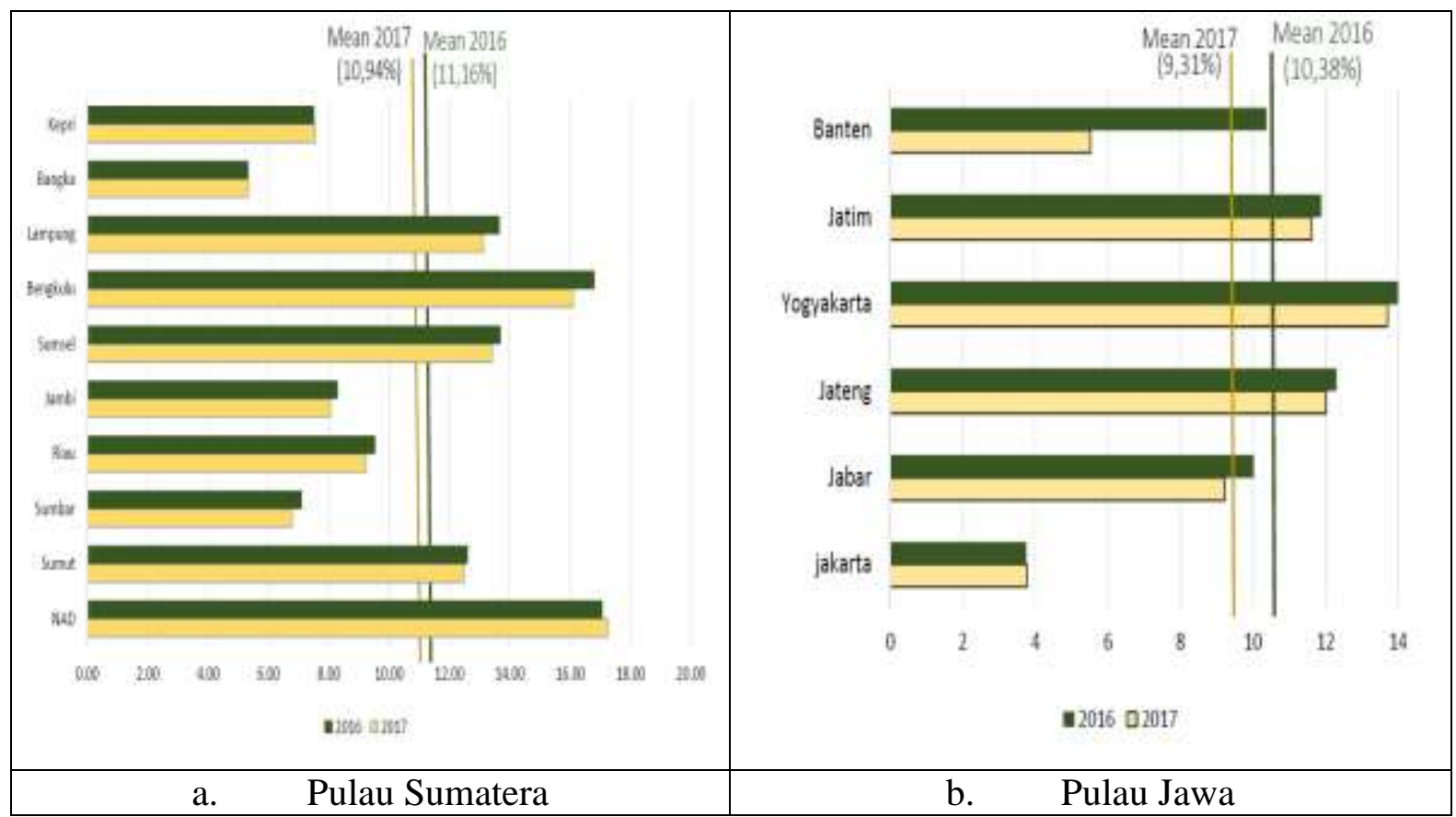

Gambar 3. Tingkat Kemiskinan Rata-rata Kabupaten/kota setiap Provinsi tahun 2016 dan 2017

Sumber: BPS. Data diolah

Sementara itu, untuk tingkat kemiskinan kabupaten/kota rata-rata di Jawa berkisar antara 3,75\% - 14\% di tahun 2016 (Gambar 3b), dimana tingkat kemiskinan kabupaten/kota ratarata yang tertinggi berada di Provinsi Yogyakarta. Sebaliknya, tingkat kemiskinan terendah berada di Provinsi Jakarta. Ternyata peningkatan kemiskinan hanya terjadi di Jakarta untuk pulau Jawa, walaupun hanya meningkat sebesar 0,02\%. 
Dengan membandingkan Gambar 3a dan 3b, terlihat tingkat kemiskinan kabupaten/kota rata-rata di Jawa lebih rendah daripada di Sumatera. Bahkan keberhasilan kabupaten/kota di Jawa dalam menurunkan kemiskinan juga selama 2016-2017 juga lebih baik dibandingkan kabupaten/kota di Sumatera. Tingkat kemiskinan kabupaten/kota rata-rata di Jawa menurun sebesar 1,07\% di tahun 2017, dibandingkan di Sumatera yang hanya turun sebesar 0,71\%. Di antara 16 provinsi di Sumatera dan Jawa, tingkat kemiskinan terendah di provinsi Jakarta, sebaliknya tingkat kemiskinan tertinggi di provinsi NAD.

Berikutnya dideskripsikan belanja pemerintah daerah yang disajikan dalam Gambar 4a (Sumatera) dan 4b (Jawa). Rata-rata belanja pemerintah kabupaten/kota di pulau Sumatera adalah Rp1,24 triliyun. Provinsi Jambi memiliki belanja pemerintah kabupaten/kota ratarata yang tertinggi (Rp1,73 triliyun), sebaliknya, belanja pemerintah kabupaten/kota ratarata yang terendah berada di Provinsi Kepri (Rp0,84 triliyun).

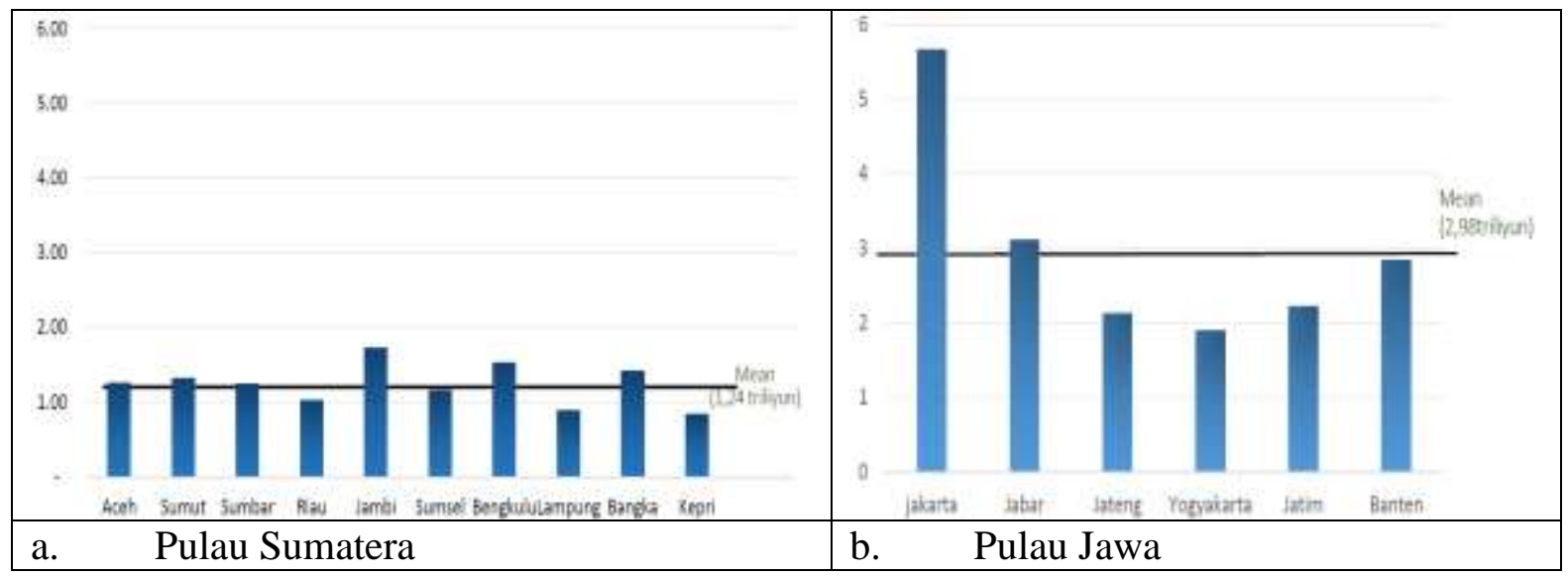

Gambar 4.Total Belanja Pemerintah Daerah dalam Satu provinsi Tahun 2017 (dalam triliun rupiah)

Sumber: Kementerian Keuangan RI. Data diolah

Sementara itu, di Pulau Jawa, rata-rata belanja pemerintah kabupaten/kota tertinggi terjadi di Provinsi DKI Jakarta. Sebaliknya, belanja pemerintah kabupaten/kota rata-rata terendah di Provinsi Yogyakarta. Bahkan rata-rata belanja pemerintah kota di provinsi Jakarta adalah yang belanja terbesar di Jawa dan Sumatera. Dibandingkan kedua pulau, belanja pemerintah kabupaten/kota rata-rata di pulau Jawa jauh lebih besar daripada di Sumatera. Dengan rata-rata belanja pemerintah kabupaten/kota sebesar Rp2,98 triliyun, maka dapat dikatakan belanja pemerintah kabupaten/kota di Jawa dua kali lipat lebih besar daripada Sumatera. Sangat besarnya belanja rata-rata pemerintah kabupaten/kota di Pulau Jawa 
disebabkan oleh jumlah penduduk di pulau Jawa yang jauh lebih banyak daripada Sumatera. Selain itu, perkembangan perekonomian di Jawa juga lebih maju sehingga penerimaan pemerintah daerah melalui pajak juga jauh lebih besar. Dengan demikian, belanja pemerintah kabupaten/kota di Jawa menjadi logis.

Variabel independen berikutnya yang diuraikan adalah pertumbuhan ekonomi di Jawa dan Sumatera. Variabel ini dijelaskan dalam Gambar 5a dan 5b. Di Sumatera, kabupaten/kota di Provinsi Kepri mengalami pertumbuhan ekonomi terendah, diikuti oleh kabupaten/kota di Provinsi Riau. Sebaliknya, pertumbuhan ekonomi rata-rata tertinggi dicapai oleh Provinsi Sumatera Barat (5,53\%). Pertumbuhan ekonomi rata-rata kabupaten/kota di Sumatera adalah $4,84 \%$.

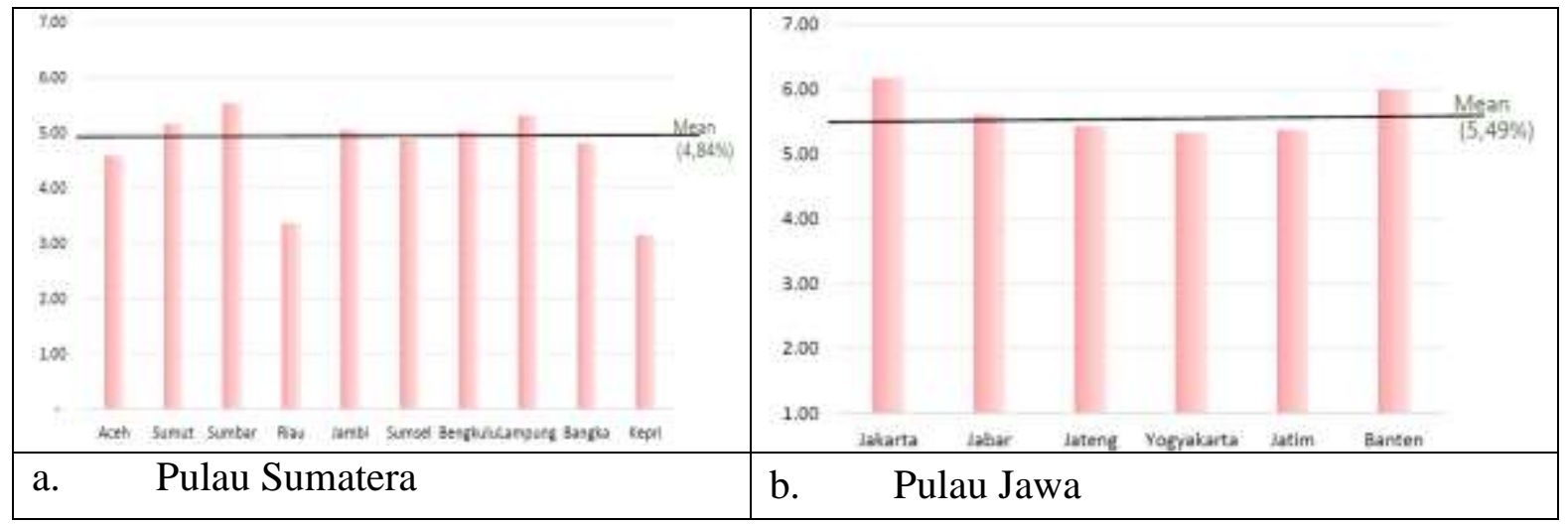

Gambar 5. Pertumbuhan Ekonomi kabupaten/kota Setiap Provinsi di Jawa dan Suamtera Tahun 2017.

Sumber: Kemenkeu RI. Data diolah

Sementara itu di Pulau Jawa, pertumbuhan ekonomi kabupaten/kotra rata-rata terendah berada di Provinsi Yogyakarta, yang tumbuh sebesar 5,33\%. Pertumbuhan ekonomi ratarata tertinggi terdapat di Jakarta, sebesar 6, 17\%. Hal ini wajar mengingat Provinsi Jakarta merupakan ibukota Indonesia dan juga pusat bisnis terbesar, sehingga peningkatan PDRB di provinsi ini menjadi yang terbesar. Kemudian, bila dilakukan perbandingan pertumbuhan ekonomi rata-rata kabupaten/kota antara kedua pulau ini, ternyata pertumbuhan ekonomi rata-rata di Jawa lebih tinggi daripada Sumatera. Di Jawa, perekonomian kabupaten/kota tumbuh rata-rata 5,49\%, sedangkan di Sumatera 4,84\%.

Setelah diuraikan deskripsi data penelitian, selanjutnya akan dijelaskan pengujian hipotesis penelitian (Tabel 1). Dari Tabel 1, untuk uji F, probabilitas F sebesar 0,000 
menunjukkan bahwa H0 ditolak. Maka secara bersama-sama belanja pemerintah, pertumbuhan ekonomi dan tingkat kemiskinan tahun sebelumnya secara signifikan mempengaruhi tingkat kemiskinan.

Tabel 1. Hasil Pengolahan Data Penelitian

\begin{tabular}{lrrrr}
\hline & \multicolumn{1}{c}{ C } & \multicolumn{1}{c}{ Ln E } & \multicolumn{1}{c}{ G } & \multicolumn{1}{c}{ Pov t-1 } \\
\hline Coefficient & 3,0946 & $-0,1024$ & $-0,043024$ & 0,971757 \\
T statistic & 2,7025 & $-2,453051$ & $-2,173209$ & 207,7564 \\
Significant level & $* * *$ & $* *$ & $* *$ & $* * *$ \\
$\mathbf{R}^{\mathbf{2}}$ & 0,9940 & & & \\
F Statistic & $14.618,78$ & & & \\
Prob & 0,0000 & & & \\
\hline Catatan: & & &
\end{tabular}

Catatan: significant level: $*=10 \%, * *=5 \%, * * *=1 \%$

Sumber: Hasil Penelitian

Demikian juga koefisien determinasi, dengan nilai $\mathrm{R}^{2}$ sebesar 0,994, menggambarkan kuatnya kemampuan 3 variabel independen dalam menjelaskan variasi rendah tingginya tingkat kemiskinan, yaitu sebesar 99,4\%. Dengan demikian, model regresi ini sudah tepat digunakan untuk menjelaskan pengaruh variabel independen terhadap tingkat kemiskinan di Sumatera dan Jawa.

Kemudian dilakukan pengujian hipotesis parsial dengan uji t. Tabel ini menjelaskan bahwa variabel belanja pemerintah (E) secara signifikan berpengaruh negatif pada tingkat kemiskinan. Pertumbuhan ekonomi (G) juga secara signifikan berpengaruh negatif terhadap tingkat kemiskinan. Sebaliknya, tingkat kemiskinan tahun sebelumnya $\left(\operatorname{Pov}_{t-1}\right)$ secara signifikan berpengaruh positif pada terhadap tingkat kemiskinan saat ini.

Dari hasil uji-t tersebut selanjutnya akan dibahas sebagai berikut. Variabel yang berpengaruh sangat besar pada kemiskinan di Sumatera dan Jawa adalah tingkat kemiskinan itu sendiri di tahun sebelumnya. Berdasarkan kajian review atas penelitian empiris yang ada, belum ditemukan seperti apa pengaruh variabel kemiskinan itu sendiri di tahun sebelumnya (timelag t-1) terhadap kemiskinan pada tahun ini. Variabel tersebut merupakan kontribusi penelitian ini. Hasil penelitian ini menunjukkan bahwa pengentasan kemiskinan tidak bisa instan, memerlukan waktu panjang untuk menurunkan tingkat 
kemiskinan. Kemiskinan tahun kemarin tentu harus diatasi agar berkurang di tahun ini. Sebaliknya, kemiskinan tahun ini akan menambah kemiskinan di tahun berikutnya.

Jika kemiskinan tahun ini meningkat sebesar 1\% maka akan meningkatkan kemiskinan tahun berikutnya sebesar $0,97 \%$. Jika masyarakat miskin tahun sebelumnya belum disentuh dengan berbagai program dan kegiatan pemerintah yang tepat, tentu saja mereka tetap miskin di tahun berikutnya. Bahkan bisa meningkat persentase kemiskinannya. Berdasarkan kondisi ini, maka pemerintah seharusnya mengoptimalkan pelaksanaan program dan kegiatan pengentasan kemiskinan supaya kemiskinan menurun sedikit demi sedikit.

Variabel independen lain dengan pengaruh moderat dalam menurunkan tingkat kemiskinan adalah belanja pemerintah. Model regresi dalam penelitian ini menemukan bahwa belanja pemerintah mempengaruhi secara negatif tingkat kemiskinan. Artinya belanja pemerintah dapat menurunkan tingkat kemiskinan di Sumatera dan Jawa. Hasil penelitian ini parallel dengan penelilitan yang dilakukan oleh Fan, Hazell dan Thorat (2000), Fan dan Zhang (2008), Sasmal dan Sasmal (2016), Tsai dan Huang (2016), Celikay dan Gumus (2017), Madzinová (2017), serta Hildalgo-Hidalgo dan IturbeOrmaetxe (2018).

Koefisien regresi untuk belanja pemerintah adalah 0,10. Ini berarti peningkatan belanja pemerintah kabupaten/kota sebesar $1 \%$ dapat menurunkan tingkat kemiskinan $0,1 \%$. Informasi ini penurunan kemiskinan tidak elastis terhadap peningkatan belanja pemerintah kabupaten/kota. Ada indikasi program dan kegiatan pemerintah kabupaten/kota dalam pengentasan kemiskinan belum menyentuh pemecahan masalah dan akar kemiskinan yang ada. Dengan kata lain, pemerintah kabupaten/kota harus berupaya lebih keras dalam menciptakan program dan kegiatan yang tepat bagi masyarakat miskin agar mereka dapat berusaha mandiri sehingga ke depannya jumlah orang miskin di wilayahnya terus menurun. Pemerintah kabupaten/kota seharusnya dapat mengalokasikan belanja secara optimal untuk menurunkan tingkat kemiskinan. Program dan kegiatan yang bisa meningkatkan aktivitas masyarakat kecil diberikan contoh di sini adalah program penguatan UMKM. Pemerintah kabupaten/kota dapat membuat program pelatihan untuk mendorong tumbuhnya usaha mikro, kecil dan menengah, serta pendampingan bagi 
mereka dalam mengembangkan usaha. Melalui pengembangan dan penguatan UMKM, diyakini mampu meningkatkan jumlah pekerja baru dan sekaligus meningkatkan pendapatan masyarakat menengah ke bawah.

Variabel independen lain dengan berpengaruh negatif pada penurunan tingkat kemiskinan dalam penelitian ini adalah pertumbuhan ekonomi. Hal ini sesuai dengan teori yang ada, bahwa jika ekonomi tumbuh, maka akan meningkatkan pendapatan masyarakat, sehingga akan menurunkan pendapatan. Hasil penelitian ini juga sejalan dengan penelitian terdahulu, seperti yang telah diteliti oleh Olavarria-Gambi (2003), Chambers, Wu dan Yao (2008), Affandi dan Astuti (2013), Ginting dan Dewi (2013), Perera dan Lee (2013), Jayadi dan Bata (2016), Sasmal dan Sasmal (2016), Tsai dan Huang (2016). HildalgoHidalgo dan Iturbe-Ormaetxe (2018).

Pertumbuhan ekonomi sebesar 1\% mampu menurunkan kemiskinan 0,04\%. Kemampuan pertumbuhan ekonomi lebih rendah dalam menurunkan kemiskinan dibandingkan belanja pemerintah. Hal ini menjelaskan pertumbuhan ekonomi yang menggerakkan perekonomian di kabupaten/kota ternyata tidak menyentuh kehidupan ekonomi masyarakat kecil, misalnya usaha yang padat modal, yang tidak bersentuhan dengan masyarakat menengah ke bawah. Hal ini menyebabkan tumbuhnya ekonomi tidak banyak menyelamatkan dan mengangkat masyarakat miskin untuk keluar dari kemiskinan, karena pengaruhnya hanya $0,04 \%$. Untuk itu pemerintah kabupaten/kota seharusnya menciptakan regulasi yang mendukung tumbuhnya UMKM local agar tingkat kemiskinan semakin menurun di masa mendatang.

\section{KESIMPULAN}

Peningkatan belanja pemerintah dan pertumbuhan ekonomi dapat menurunkan tingkat kemiskinan. Namun tingkat kemiskinan tahun sebelumnya juga menjadi penyebab tingkat kemiskinan saat ini meningkat. Sehingga pemerintah dan dunia usaha diharapkan dapat mencari akar permasalahan kemiskinan di kabupaten/kota masing-masing agar nantinya mampu menciptakan program dan kegiatan yang tepat yang menyentuh masyarakat miskin. Seperti pengembangan dan penguatan UMKM yang sudah ada. Selain itu perlu diciptakan program dan kegiatan yang bersifat mendorong masyarakat untuk berani membuka usaha melalui pelatihan dan pendampingan usaha. Dengan adanya program dan 
kegiatan yang tepat, secara perlahan tingkat kemiskinan di kabupaten/kota di Pulau Jawa dan Sumatera akan menurun. Progam dan kegiatan yang tepat dalam pengentasan kemiskinan juga perlu didukung oleh alokasi belanja pemerintah kabupaten/kota yang optimal.

\section{KETERBATASAN DAN REKOMENDASI}

Aktivitas pemerintah untuk mengentaskan kemiskinan tidak menjadi focus penelitian ini. Namun, karena belanja pemerintah berkaitan erat dengan program dan kegiatan yang dilakukan, maka seharusnya program dan kegiatan pemerintah juga diteliti, apakah pemerintah daerah memiliki program pro-poor atau tidak. Hal ini menjadi keterbatasan penelitian ini. Oleh karena itu, rekomendasi penelitian lanjutan dari penelitian ini adalah penggunaan variabel program pemerintah yang bertujuan mengurangi kemiskinan (pro-poor program) dalam upaya pengentasan kemiskinan. Dengan adanya informasi mengenai propoor program yang diterapkan oleh pemerintah daerah, akan terlihat apakah belanja pemerintah daerah sudah/belum tepat penggunaannya dalam mengurangi kemiskinan di Jawa dan Sumatera.

\section{DAFTAR PUSTAKA}

Adisasmita, Rahardjo. (2011). Pengelolaan Pendapatan dan Anggaran Daerah, Edisi Pertama. Yogyakarta: Graha Ilmu.

Affandi, A., \& Astuti, D.P. (2013). Dynamic model of Ibn Khaldun Theory On Poverty: Empirical Analysis On The Poverty In Majority and Minority Muslim Population After The Financial Crisis. Humanomics, 29(2),136-160. https://doi.org/10.1108/08288661311319193

Alisjahbana, A.S., \& Murniningtyas, E. (2018). Tujuan Pembangunan Berkelanjutan di Indonesia: Konsep, Target dan Strategi Implementasi. Jawa Barat: Unpad Press.

Celikay, F., \& Gumus, Erdal. (2017). The effect of social spending on reducing poverty. International Journal of Social Economics, 44 (5), 620-632. https://doi.org/10.1108/IJSE-10-2015-0274

Chambers, D., Wu, Ying., \& Yao, Hong. (2008). The impact of Past Growth on Poverty in Chinese Provinces. Journal of Asian Economics, 19, 348-357. http://doi.org/10.1016/j.asieco.2008.04.004.

Fan, S., Hazell, P., \& Thorat, S. (2000). Government Spending, Growthand Poverty in Rural India. American Journal of Agricultural Economics, 82(4),1038-1051. http://doi.org/10.1111/0002-9092.00101

Fan, S., \& Zhang, X.(2008). Public Expenditure, Growth and Poverty Reduction in Rural Uganda. African Development Review, 20(3), 466-496. 
http://doi.org/10.1111/j.1467-8268.2008.00194.x.

Ginting, A.M., \& Dewi, G.P. (2013). Pengaruh Pertumbuhan EKonomi dan Pertumbuhan Sektor Keuangan terhadap Pengurangan Kemiskinan di Indonesia. Jurnal Ekonomi dan Kebijakan Publik,

https://jurnal.dpr.go.id/index.php/ekp/article/view/167/112

Gujarati, D.N. (2006). Dasar-Dasar Ekonometrika. Terjemahan (Mc GrawHill), Edisi ketiga, Jilid 1. Jakarta: Erlangga.

Hidalgo-Hidalgo, M., \& Iturbe-Ormaetxe, I. (2018). Long-run effects of public expenditure on poverty. Journal of Economic Inequality, 16, 1-22. https://doi.org/10.1007/s10888-017-9360-z

Jayadi, D.S., \& Bata, A.G. (2016). Peran Pertumbuhan Ekonomi dalam Menurunkan Kemiskinan di Tingkat Provinsi di Indonesia Tahun 2004-2012. Modus, 28(1), 8799. https://ojs.uajy.ac.id/index.php/modus/article/viewFile/669/689

Kuncoro, M. (2003). Ekonomi Pembangunan: Masalah dan Kebijakan, Edisi ketiga. Yogyakarta: UPP AMP YPKN.

Kuncoro, M. (2013). Mudah Memahami dan Menganalisis Indikator Ekonomi. Yogyakarta: UPP STIM YPKN.

Madzinová, R. (2017). Impact Of Government Spending On Income Inequality. Annals of the University of Oradea, Economic Science Series, 26(2), 210-220. http://steconomice.uoradea.ro/anale/en_index.html

Mahmudi. (2010). Manajemen Keuangan Daerah, Jakarta: Erlangga.

Mankiw, N.G. (2007). Makroekonomi, Edisi keenam. Jakarta: Erlangga.

Olavarria-Gambi, M. (2003). Poverty Reduction in Chile: has Economic Growth been Enough. Journal of Human Development, 4(1), 103-123. http://doi.org/10.1080/1464988032000051504

Perera, L.D.H., \& Lee, G.H.Y. (2013). Have Economic Growth and Institution Quality Contributed to Poverty and Inequality Reduction in Asia? Journal of Asian Economics, 27, 71-86.

Sasmal, R., \& Sasmal, J. (2016). Public Expenditure, Economic Growth and Poverty Alleviation. International Journal of Social Economics, 43(6), 604-618. http://doi.org/10.1108/IJSE-08-2014-0161

Tsai, Pan-Long., \& Huang, Chao-Hsi. (2007). Openness, Growth, and Poverty: The Case of Taiwan. World Development, 35(11): 1858-181. http://doi.org/10.1016/j.worlddev.2006.11.013 